Article

\title{
Citizen Journalism and Public Participation in the Era of New Media in Indonesia: From Street to Tweet
}

\author{
Rajab Ritonga ${ }^{1, *}$ and Iswandi Syahputra ${ }^{2}$ \\ ${ }^{1}$ Faculty of Communication, Universitas Prof. Dr. Moestopo (Beragama), 10270 Jakarta, Indonesia; \\ E-Mail: rajab.ritonga@dsn.moestopo.ac.id \\ 2 Study Program of Communication Sciences, Faculty of Social Sciences and Humanities, Sunan Kalijaga State Islamic \\ University of Yogyakarta, 55281 Yogyakarta, Indonesia; E-Mail: iswandi.syahputra@uin-suka.ac.id \\ * Corresponding author
}

Submitted: 16 March 2019 | Accepted: 12 June 2019 | Published: 6 August 2019

\begin{abstract}
Citizen journalism was initially practiced via mass media. This is because citizens trusted mass media as an independent information channel, and social media like Twitter was unavailable. Following mass media's affiliation to political parties and the rise of social media, citizens began using Twitter for delivering news or information. We dub this as citizen journalism from street to tweet. This study found that such process indicates the waning of mass media and the intensification of social media. Yet, the process neither strengthened citizen journalism nor increased public participation as it resulted in netizens experiencing severe polarization between groups critical and in support of the government instead. We consider this as a new emerging phenomenon caused by the advent of new media in the post-truth era. In this context, post-truth refers to social and political conditions wherein citizens no longer respect the truth due to political polarization, fakenews-producing journalist, hate-mongering citizen journalism, and unregulated social media activities. Primary data were obtained through in-depth interviews with four informants. While conversation data of netizens on Twitter were acquired from a Twitter conversation reader operated by DEA (Drone Emprit Academic), a big data system capable of capturing and analyzing netizen's conversations, particularly on Twitter in real time. This study may have implications on the shift of citizen journalism due to its presence in the era of new media. The most salient feature in this new period is the obscurity of news, information, and opinions conveyed by citizens via social media, like Twitter.
\end{abstract}

\section{Keywords}

citizen journalism; Indonesia; mass media; new media; public participation; social media; Twitter

\section{Issue}

This article is part of the issue "Civic Organizations and Digital Technologies in an Age of Distrust", edited by Eric Gordon (Emerson College, USA).

(C) 2019 by the authors; licensee Cogitatio (Lisbon, Portugal). This article is licensed under a Creative Commons Attribution 4.0 International License (CC BY).

\section{Introduction}

There are two issues discussed in this article. The first is citizen journalism, while the second is mass media politics in Indonesia. Both relations are placed within the context of the advent of new media, specifically Twitter, and public participation. According to Lang (2010), citizen journalism may be construed as a form of journalism produced by nonprofessionals. Citizen journalism prod- ucts may take the form of texts, images, videos, and audios. The production process may involve tools like mobile phones, computers, audio recorders, or even mere pen and paper. Historically speaking, Flew (2014) explains that citizen journalism emerged in 1999 following a publication by Matthew Arnison and others involved in a group known as 'Active Sydney'. This group began receiving numerous information from various sources for various new forms of news production. 
Then in 2000, a website called OhmyNews.com popped up in Korea. This site was initiated by a former journalist, Oh Yeon-Ho, who was dissatisfied with traditional mass media reporting. He argues that journalists are not an exotic species. They are people who possess news and share it with others. This is why the motto of Ohmynews.com is "Every Citizen is a Reporter". In its early development, OhmyNews.com began its activities by using 727 citizen reporters and 4 editors. After 5 years, the amount increased to 38,000 citizen reporters and around a dozen editors (Kolodzy, 2007).

The emergence of Ohmynews.com as a form of citizen journalism did not only take place in Korea but the whole world. Various literature suggests that early 2000 is recorded as a start in the rise of what is known as indymedia (see Lessig, 2001). There were at least 80 kinds of indymedia practicing citizen journalism. The emergence of indymedia at the time was driven by the political backdrop of creating space for citizens in expressing their concerns and showing their interests on various global and local public issues. Indymedia, which came about as a form of citizen journalism via website, was more feasible for citizens on account of the internet's capacity to organize and keep archive of news, which traditional media is incapable of (Pavlik, 2001), and the extraordinary ability to interact among internet users (Schultz, 2000). Since it is based in freedom of expression and citizen interest, the advent of indymedia had resulted in various forms of communities (Ball-Rokeach \& Gutierrez-Hoyt, 2001). The communities emerging from the internet-based Indymedia power had the potential to surpass the power of traditional media (Chadka \& Kavoori, 2000; Kerr, 2001). Nevertheless, in the Indonesian context, citizen journalism did not begin from citizens' activities on the internet. Citizen journalism first appeared from the news report of Elshinta Radio, Jakarta, which is a traditional media (Kurniawan, 2007; Kurniawan \& Loo, 2007; Sukartik, 2016; Widodo, 2010).

The second issue refers to mass media politics in Indonesia. The most emerging debate within this topic concerns with the question of whether mass media affects politics, or politics affect media, or do both mutually influence each other. Normatively speaking in the political perspective, mass media functions as an instrument of control in state administration (Curran, 2007). This perspective believes that independent media can contribute to the democratic process by providing access to information that the public needs or by offering freedom of expression to citizens (Low, 2003). In short, mass media serves as watchdog to the state. While to the public, it functions as an information provider and arena for expressing public opinions.

However, mass media in Indonesia today no longer takes on both roles properly. This is on account of media ownership being under the control of conglomeration practices (Lim, 2011; Nainggolan, 2017; Nugroho, Putri, \& Laksmi, 2012; Nugroho, Siregar, \& Laksmi, 2012; Syahputra, 2013). Concurrently, media conglomerates also assume positions as political party leaders. Mietzner (2015) considers this as a period of decline for Indonesian democracy. Meanwhile, Syahputra (2013) refers to this as the media regime. Media ownership by conglomerates who founded political parties and became its leader have resulted in their exploiting the media for political interests rather than keeping its function as state watchdog or arena for forming public opinions (Lim, 2012). The conglomerates wield extraordinary power as they simultaneously control mass media and political party (Castells, 2009). As a result, the media becomes partisan and the public has no outlet for conveying their opinions.

Such conditions have become more pronounced during periods leading up to general elections such as the 2014 or 2019 presidential elections. Approaching the 2019 Presidential Election, medias owned by political parties are dragged into becoming partisans, which consequently skews the media's ideal reality. However, the rise of social media became an alternative for citizens to reinstate their function of public control over the administration of state. Additionally, netizens' activities on social media even perform control over the operation of mass media. Social media has become a discursive space capable of inciting political mobilizations and mass protests. In Indonesia, intense social media activities could even impact social movement and induce political change (Lim, 2014; Nugroho \& Syarief, 2012).

This is the most recent portrait of relations between the public, the media, and the state in Indonesia. A condition wherein the public distrusts mass media due to its political partisanship. Meanwhile, rising public participation and activities are found on social media. In this context, public participation is mediated through their activities on social media, since mass media is considered to have neglected its function as the state's watchdog. Public participation is, hence, of utmost importance in the new media era within the context of social and political lives in a country like Indonesia. Public participation may be defined as "the process by which public concerns, needs, and values are incorporated into governmental and corporate decision making. It is two-way communication and interaction, with the overall goal of better decisions that are supported by the public" (Creighton, 2005, p. 7).

The above definition explains that public participation is neither coincidental nor unintentional. Public participation is not only the process of involving the public in providing the information they need. It is a process of interactions among citizens, or between citizens and state administrators or various private institutions. According to Keeter (2003), public participation is indicated by the following: (1) the participation concerns public issues and solutions; (2) public participation is voluntary; (3) the public is citizens, or members of a group or organization.

These various conditions are new phenomenon concerning the relationship between public participation and citizen journalism. It's a rather complicated relationship to simplify as it involves various well-established un- 
derstandings and factors. For instance, citizen journalism is not as simple as Lang (2010) mentioned, because the forms of journalism produced by non-professionals are no longer simple. The products of citizen journalism in the form of texts, pictures, videos, and audios are made using tools like cell phones, computers, audio recorders, or even plain pen and paper then distributed via conventional (traditional) mass media.

In the context of Indonesia today, the process appears with various complex specifications due to the presence of social media with rather high level of netizen activities and mass media politically affiliated to presidential candidates running for the presidential election. As a result, polarization based on differing political orientation in the presidential election emerged among the netizens. This consequently led to the citizen journalism process being formed by various political orientations from the polarized netizens. The polarization places mass media as one of the partisan actors. Thus, the advent of citizen journalism politically is a manifestation of their participation in civic life. In such context, the concept of public participation also changes, and it is no longer "the process by which public concerns, needs, and values are incorporated into governmental and corporate decision making. It is two-way communication and interaction, with the overall goal of better decisions that are supported by the public" (Creighton, 2005, p. 7). Public participation becomes political identity in the public sphere through various citizen journalism practices and conversations on social media, particularly Twitter.

Given such background, this study assumes that citizen journalism through their activities on Twitter in the new media era within the context of mass media deviance may drive or alter public (netizen) participation. This explains that public participation has undergone a shift. Citizen journalism as a form of public participation was previously distributed via mass media. Yet, today, citizen journalism as a form of public participation is produced, distributed, and talked about via Twitter. Initially, public participation is understood as a process of public involvement in the government's decision-making process, but today, public participation is the practice of identity politics by polarized citizens. Therefore, the problem statement of this study is how did citizen journalism as public participation in the context of new media in Indonesia shift from street to tweet?

\section{Methodology}

Data in this study were gathered through the combination of various techniques in various different stages. At the initial stage, data were gathered through online participation-observation. Hence, a social media account on Twitter was made at the onset of the study. Then, the researcher socialized with other accounts, particularly those that frequently practice citizen journalism. This was carried out in order to obtain inside perspectives from the netizens.
The gathered data were subsequently divided into three different kinds. First, elicited data acquired from communities or Twitter accounts practicing citizen journalism. Second, field-note data acquired during in-depth interviews with selected number of sources. There were four informants in this study in which three of them are netizens active on Twitter. The minimum requirement set to be a source in this study is that they have disseminated citizen journalism product via Twitter. Additionally, one informant is a former executive producer of Elshinta Radio who managed the Information from You (IDA) program as a form of citizen journalism in the pre-Twitter era. The object of this research is to find the various relations interlinked with citizen journalism as a form of public participation in the context of new media in Indonesia that can alter the for of citizen journalism from street to tweet. This study began by observing the timelines on Twitter with special attention to materials containing citizen journalism as a form of public participation.

Third, archival data in the form of archives or documents in writing, pictures, or video recordings produced, distributed, and responded by fellow netizens or saved in Twitter. These are conversation data among netizens on Twitter, and they were obtained via a Twitter conversation reader operated by DEA (Drone Emprit Academic), which is a big data system with the ability to capture and analyze netizens' conversations on social media, particularly Twitter in real time.

The next stage was identifying Twitter accounts (both pseudonymous and actual) that contain citizen journalism as a form of public participation in the new media era to be interviewed. Selection of citizen journalism bearing contents employed the three indicators from Keeter (2003) namely: (1) contents relating to public issues and public problem solving; (2) public (netizen) participation is voluntary; (3) the public is citizens or members of a group or organization.

The interview began with the most distinctive general question, "What is your opinion about citizen journalism as a form of public participation in the new media era?" Then the interview led to several more specific questions to find various relations that interlink with citizen journalism as a form of public participation in the context of new media in Indonesia that can alter the form of journalism from street to tweet. For instance, "Why was the journalistic work you made distributed via social media (Twitter) instead of mass media?" or "How do you assess something you are about to post on Twitter as important to the public?" The interviews were done in Jakarta throughout the month of September 2018.

The collected data were compiled thematically based on the information obtained from the interviews and observation of conversations on Twitter timelines. Data compilation was done by arranging issues relevant with the study. the final part of the data analysis method involved data interpretation by using various data validity tests through triangulation theory or theoretical perspective. The data obtained was subsequently pro- 
cessed through several categories leading to attempts at generalization which was then presented in an interpretative and descriptive manner to answer the problem statement.

\section{Research Findings and Discussion}

\subsection{Perspective of Citizen Journalism in Indonesia, from Local to National Conversations}

In Indonesia, citizen journalism in the form of public participation can be traced back to when Radio Elshinta, News and Talk Jakarta began broadcasting news from citizens. Radio Elshinta involved its listeners to provide information other citizens needed. According to Kurniawan (2007) and Kurniawan and Loo (2007), since Elshinta started to become a news radio (2000 to 2007), it maintained 100,000 citizen reporters. Kurniawan mentioned that internet use in Indonesia was still low at the time. Additionally, the public's level of education was low and there was a strong verbal culture amongst the public, this led to Elshinta's success in involving the public to engage in citizen journalism.

Meanwhile, Sukartik (2016) in his research expounds that Elshinta radio oversees a national network, and it constantly involves the public to send news and information. According to informant 1 (initial TA), who is a former executive producer and senior broadcaster of Elshinta radio, public participation is specifically allocated in the IDA program:

IDA is a program designed to accept and disseminate any information from Elshinta listeners as Indonesian citizens wherever they may be and can tune in to Elshinta. The information can get responses from other listeners from Elshinta's entire broadcast area all over Indonesia. In practice, various information from citizens are not only broadcasted via the IDA program but they would also appear briefly in other programs.

To Elshinta, news or information from citizens are crucial and prioritized for immediate broadcast. As of current, the process of sending news and information, done through short messages (SMS), emails or direct reports via telephone, remains the same. Elshinta radio and its citizen journalism program was subsequently followed by other radio stations having national or local coverage like Suara Surabaya radio (Adi, 2016).

By prioritizing news or information from the public, anywhere they may be in Indonesia, they provide an understanding of local events that may turn into a national conversation. This is due to the fact that when information or news from a member of the public is broadcasted, it would often garner responses from other citizens all over Indonesia. Such interaction enables every citizen to find new ways of facilitating direct interactions amongst themselves, which had formerly been obstructed by dis- tance. According to Gordon and Silva (2011), this perspective emphasizes the use of locally-based communication technology driving every citizen to develop local awareness. This local awareness generates new connotations such as distributing information or local news that are considered special, and it positions locals as participative and collaborative agents. Local awareness subsequently creates geographical context for data and networks of news and information.

At this stage, citizen journalism comes in the form of coverage concerning information considered important to the public such as traffic accidents, missing persons, or criminal information like theft. Such information is conveyed voluntarily by citizens to other citizens. The practice of citizen journalism through Elshinta radio as a mass media is a form of public participation to influence government in making decisions. According to Informant $A$ (initial TA), information from citizens does not only impact government performance but it also assists the public in responding to every problem they face.

Many citizens gain benefit from information provided by other citizens via Elshinta radio. For your information, government personnel also keep listening to Elshinta radio to find out what citizens experience or want. In many cases of citizen report such as collision causing traffic jam, it could help the police in guiding traffic and is an important information for other motorists.

Various patterns or forms of interactions among the public pertaining to local news or information will become more extensive and massive due to the advent of new media. Unlike the advent of local news or information through radios like Elshinta, in the new media era, local news or information dissemination does not go through a gate keeper process as mass media does or a queue list for broadcast. The social space brought about by new media's presence has produced a common platform for social and political interactions amongst the citizenry. The cyber world's social space has become a highly active element in producing social relations (Kitchin \& Dodge, 2011), and concurrently produced by social interactions (Lefebvre, 2016).

Gordon and Silva (2011) consider these public activities as a collective process of public empowerment. Hence, 'locality' is no longer defined in terms of physical proximity as the citizens using these communication technology devices can mutually interact, regardless of the distant physical conditions they are in. At this stage, citizen journalism can no longer be understood as a citizen's act in finding, acquiring, having, keeping, processing, and conveying information or news in the form of writings, audios, visuals, audio and visual, and data or in other forms via mass media either printed or electronic. At this stage, citizen journalism is a form of public participation indicated by four essential factors, namely: first, without the gatekeeper process, which commonly occurs 
in the journalistic process of mass media. Second, the process happens in real time, anywhere and everywhere any citizen can conduct journalistic practices. Third, the practice of citizen journalism as a form of public participation is able to stimulate conversations massively on Twitter. Fourth, netizens as virtual citizens involved may appear in the form of anonymous account on social media. this is the first part of the change to the next stage that we call information disruption.

In this context, we define information disruption as change that occurs as a result information being able to be produced, distributed, and consumed by anyone, anytime, and anywhere with ease. This is a more specific definition because the context of interaction among citizens is via social media, Twitter. A broader understanding may define this as disruptive technology (Danneels, 2004). This understanding assumes that information disruption occurs due to the advancement of communication technology.

The information disruption stage seems to be in more chaotic in Indonesia given that concurrently there are very dynamic political activities leading up to the 2019 presidential election. Hence, it is extremely difficult to differentiate between actual information from citizens for public good, or fake information and hoaxes to delegitimize the other group that has differing political inclination. This stage is indicated by two essential factors, namely the waning of mass media along with the intensification of social media and citizen journalism as public opinions. We name this stage as the post-truth era.

\subsection{The Waning of Mass Media: The Intensification of Social Media in the Post-Truth Era}

Today, internet use by the Indonesian public has influenced public participation changes or developments in the practice of citizen journalism. According to a survey by the Indonesian Internet Service Providers Association (APJII, 2017) until 2017, the number of internet users in Indonesia reached 143.26 million or $54.68 \%$ from the total Indonesian population of 262 million. This amount continues to increase year by year. Data from We Are Social (2018) states that 130 million or $49 \%$ of Indonesians were active on social media. Approximately 35 million or $27 \%$ of the population actively used Twitter for various activities. The data shows that Twitter users in Indonesia are considered as the most productive in the world. In 2014, Indonesia placed fifth on the world tweeting rank. While, actually, at the time Twitter reported Indonesian users had only reached 29 million (Lukman, 2013).

One interesting thing about Twitter when compared to other social media is its Twittersphere as an active discussion forum particularly for social and political issues among citizens. Due to this feature, Twitter is often claimed as a type of social media capable of making predictions (Asur \& Huberman, 2010). Nevertheless, Twitter has its weakness because Twitter users are not samples representing a population, due to the fact that its use is favored by urban population or those with good economic capacity (Hecht \& Stephens, 2014; Malik, Lamba, Nakos, \& Pfeffer, 2015; Mislove, Lehmann, Ahn, Onnela, \& Rosenquist, 2011). In addition to that weakness, Twitter is also frequently used for various particular interests such as popularizing a product or harassing others by involving robot accounts automatically used through the computer's script system (Donath, 2007; Thomas, Grier, \& Paxson, 2011; Thomas, McCoy, Grier, Kolcz, \& Paxson, 2013). Hence, it is quite vital that communities, opinion leaders or new norms emerge from activities on Twitter in a cyber culture.

The relationship between citizen journalism and public participation on Twitter, hence, develops within a cyber culture chock-full of various activities mediated via the internet. Fellow members of the society can be connected expansively, rapidly, and in real time, despite never having met one another. Therefore, Lévy (via Macek, 2004) uses the term cyber culture in referring to the internet as a virtual space. Lévy argues, the internet's rise brought about various new forms of message distribution. This is why cyber culture is known for its changes in technical (communication) devices, practical habit, attitude, mindset, and values that develop along with the virtual world.

The effect of communication technology in the new media era that manifested in various ease of access to anything over the internet have shifted the public's pattern in consuming and distributing information. Information is easily found on the internet and can be modified to be redistributed via numerous social media channels. Social media platforms like Twitter have become a means for exchanging information among the public (Lim, 2017). Any citizen with access to the internet or social media can act as an agent of social even political change (Gordon, 2017). In some countries, public interactions on social media have triggered social and political changes.

Public participation and interaction have become active terms in the current era of new media. Citizens interconnected and mediated by the internet are known as netizens, a term initially coined by Michael Hauben in 1995 combining the words network and citizens. Netizens may be defined as citizens who are active and mutually interact within an internet network system (Hauben \& Hauben, 1997). According to Levinson (2014), the new public interaction within cyber culture is regarded as new new media, i.e. all information in all forms being distributed more rapidly and expansively thereby leading to the formation of new concepts, new lifestyles, and even new forces in political activities.

According to informant 2 (initial HSW), a social media activist in Indonesia, interactions or conversations among netizens on social media, particularly Twitter, increase exponentially when pertaining to the 2019 Presidential Election. The rise of conversations on Twitter has polarized netizens into two major groups. The first group represents the Presidential and Vice-Presidential 
candidates of Joko Widodo and Maruf Amin (Number 01), while the latter represents the Presidential and Vice-Presidential candidates of Prabowo Subianto and Sandiaga Uno (Number 02). On Twitter, this polarization is frequently observed in the form of hashtag wars:

There is a tendency that Indonesian netizen conversations intensify when discussing politics, particularly when relating to the 2019 presidential election. However, upon closer observation, this intensification has a pattern. For instance, when a significant incident is not broadcasted by mass media to the public, netizens take on the role of discussing it on Twitter until it goes viral. Upon closer examination, the process of making things unreported by mass media go viral originates from netizen groups of similar political affiliation, that is the opposition group. Upon even closer examination, this condition may appear because mass media has politically been coopted by the reigning nonopposition group. So, Twitter becomes an alternative media in political participation for expressing the dissenting opinions of the citizens. Through Twitter, these opinions can easily go viral on account of one of Twitter's features, namely the hashtag.

According to Bruns and Burgess (2011) Twitter hashtag is a brief keyword that begins with the '\#' symbol. Hashtags function as a means to coordinate, consolidate, and distribute news/information to more netizens. If a hashtag becomes the talk among netizens, then it would have greater influence on other netizens on Twitter. This is due to Twitter's capability of disseminating information via mentions, retweets, hyperlinks, hashtags, and other functions (Ausserhofer \& Maireder, 2013). Hashtag wars may occur as seen in Figure 1.

Hashtag wars are at the forefront, the most obvious and the most frequent to appear on Twitter in relation to netizens' conversations about politics leading up to the 2019 presidential election. These data in the form of SNA maps can, thus, be read or understood in three ways, namely:

First, netizens' conversations experienced polarization into two large groups representing two political interests. Polarization was established based on differing political identity leading up to the 2019 presidential election. As a result, when netizens identified as opinion leaders within each group convey (nonpolitical) information as a form of citizen journalism relating to the wider public interest, they do not receive any support from the opposing group. Netizens' political polarization on Twitter disregards the wider public interest (Syahputra, 2017).

Second, data from the SNA maps showing this polarization indicates the absence of mass media. Mass media are, seemingly, uninterested in being present to provide proper analysis or information in response to the prevalence of the political identity based polarization. To the netizens and the opposition, mass media is considered as being affiliated to and coopted by the ruling political elites. Nevertheless, in some of the cases observed on Twitter, several mass media coverages had also been

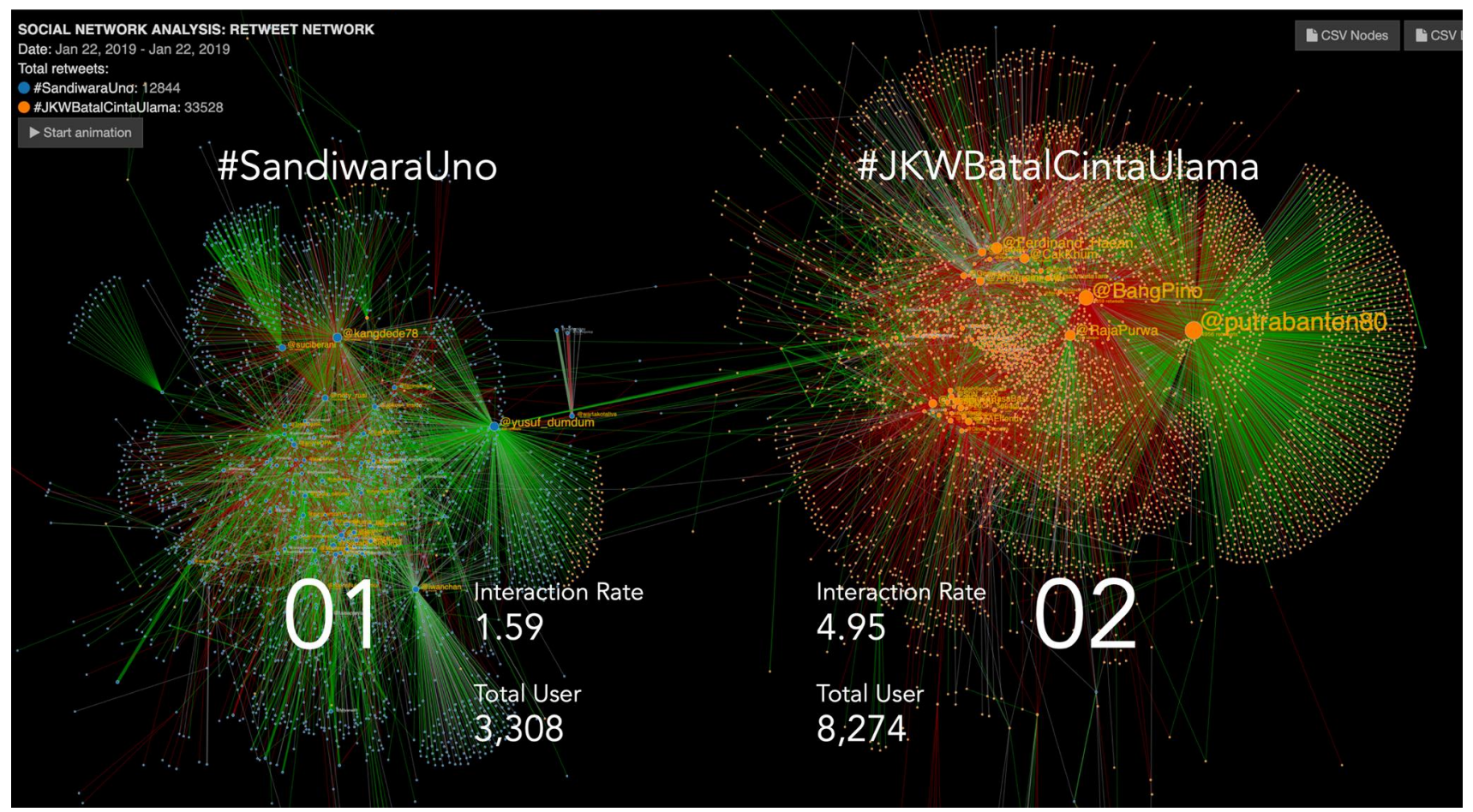

Figure 1. SNA (Social Network Analysis) map of netizens' chats on Twitter referring to the hashtag wars between the number 01 Presidential Candidate pair (Jokowi-Ma'ruf Amin) and the number 02 Presidential Candidate pair (PrabowoSandiaga) on 22 January 2019. Source: DEA (2019). 
used to support the opposition group. Although they often criticize mass media for having been coopted by the ruler, mass media news is also trusted because they benefit from the coverages. This also applies vice versa, mass media coverages are used to support the ruling group because they think they gain benefit from them. This second point emphasizes that mass media coverage concerning politics in Twitter conversations among netizens who experienced polarization means nothing since it constantly enters an established polarized sphere of netizens.

Third, the two points have greater impact on citizen journalism activities. An example is when a netizen unaffiliated to any group conveyed important information to the public. Concerning the abuse of Audrey, a junior high student in Pontianak, as a practice in citizen journalism that went viral. It went viral because it was posted by an opinion leader from one of the groups with the hashtag \#JusticeForAudrey (Santoso, 2019). This was then covered by mass media, but it did not gain the support of other groups from the opposing political view. This continued up to the point that each group became trapped in a polarization of unilaterally defending the truth.

Therefore, we intend to explain this as a new emerging phenomenon brought about by the advent of new media in the post-truth era. The term post-truth was first introduced in 1992 by Steve Tesich in The Nation. It was initially used to reflect the Gulf War and the case of Iran occurring in that period. The term was then popularized by Keyes (2013) in his book The Post-Truth Era. As a journey, post-truth is a concept attached to a particular period (Besserman, 1998; Green, 1995). Yet, it refers to similar issues regarding public concern over truth claims. Citizens involved in truth claim are likened to a teller peddling truth.

In the new media era, post-truth may be recognized through various discursive spaces on social media like Twitter. Chats on Twitter that transpire constantly, massively, and rapidly may lead to trust or distrust in honesty, deceit, truth, virtue or vice, and in anything wanting to be considered as truth. Informant 3 (initial EN), a journalist active on Twitter, explained that journalists and media can be actors in the formation of truth emerging in discursive spaces on social media, like Twitter:

Through certain techniques such as framing, truth can be established once it is constantly reported by mass media. The news will then become conversations on Twitter. The netizen group that massively and incessantly support this news will consider the news or information as the truth. This process becomes easier because netizens had initially been polarized by political emotions.

This study found that the polarization of netizens in the post-truth era is also a result of mass media's deviating function or journalists' biases in the reporting process. Mass media no longer assumes its main function as a provider of objective and neutral information to the public and as a watchdog of the state. Consequently, netizens with opposing political choices in the Presidential Election express their differences in an increasingly intensive and infuriated manner on account of the media's absence as an alternative source of information for the public. While in fact, the media should provide important information concerning political news coverage leading up to the presidential election to help citizens make their decision (Strelitz \& Steenveld, 1998).

Such situation had developed because mass media has been run by conglomeration principles and is controlled by conglomerates who are also leaders of political parties affiliated with power (Lim, 2011; Nugroho et al., 2012; Syahputra, 2013). These various relations are the most significant reason for the intense, profane, and hate-speech-ridden activities observed to occur on Twitter. The following SNA data on netizens' activities on Twitter describes the absence of mass media as an information provider to the public. In Figure 2, media was not present to mediate the two groups of netizens and provide objective information required by both sides while they were discussing the presidential election on Twitter. Mass media's absence as a provider of information when netizens discussed various public issues had reinforced the polarization instead.

In this context, post-truth is a description of social and political conditions wherein the public no longer respects the truth on account of political polarization, unethical journalists produce fake news, hatred-inducing citizen journalism emerges on account of political differences, and disorganized social media activities prevails. Politicians, journalists, citizens, scholars, and even, in the Indonesian context, ulemas only accept what they believe or feel is true based on emotional drive or interest. This itself is an ethical challenge for journalistic activities in producing news in the post truth era (White, 2017). The relations of these various conditions, i.e. the fading mass media and the strengthening of social media in the post-truth era, have shifted the practice of public or citizen journalism into a practice of expressing public opinion. According to informant 4 (initial SR), a lecturer active on Twitter, this change indicates three things, namely:

First, the public's trust in mass media has declined due to the media's political partisanship. Second, people are more interested in politics because it concerns a wider public interest. Third, social media like Twitter can be present as a public space where people can freely express their opinions.

This shift occurs because of changes in patterns of interactions between the public and the media, as well as among the citizenry themselves. This new attribute allows anyone active on social media to engage and be involved as information consumers as well as producers. Every activist or social media user even plays a role as a message distributor (Weeks \& Holbert, 2013). 


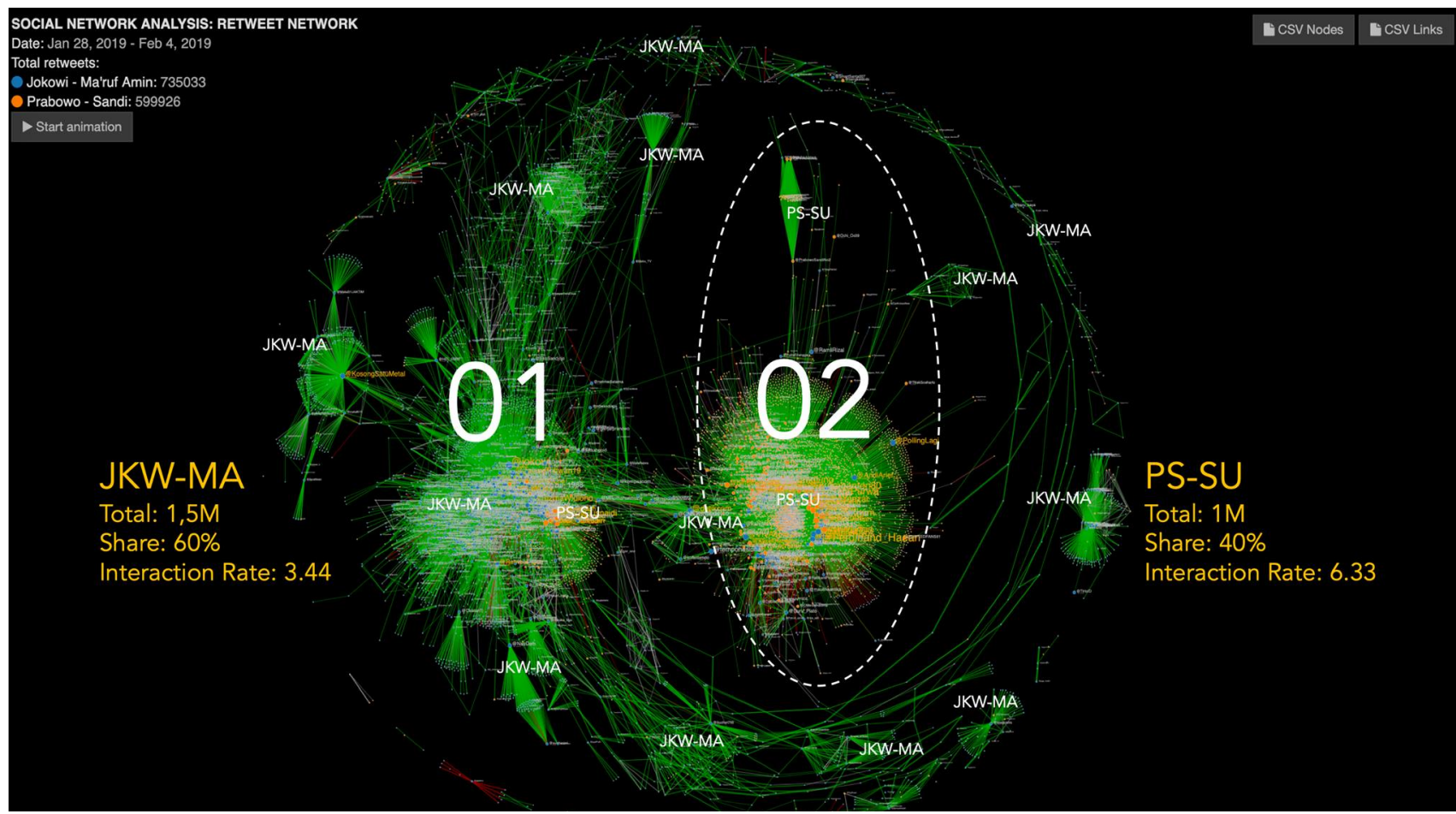

Figure 2. SNA map of netizens' conversations on Twitter concerning the Presidential Election between the Number 01 pair of candidates (Jokowi-Ma'ruf Amin/JKW-MA) and the Number 02 pair of candidates (Prabowo-Sandiaga/PS-SU) on 28 January 2019 and 4 February 2019. Source: DEA (2019).

This indicates a shift from the mass communication era to the internet-based communication era (Khang, Ki, \& Ye, 2012). Formerly, the relation between the public and the media placed citizens as passive recipient of media messages. However, technological advances have altered the situation. The invention of the internet along with its communication tools have provided the public the freedom to openly express their voices. People would mutually create, share, and comment on news/information relating to public interest. The participatory notion of users and their active (instead of passive) role in the news-making process have led to the 'idea' of citizen journalism.

\subsection{Citizen Journalism as Public Opinion}

According to Kolodzy (2007), citizen journalism can be construed as citizens active in the process of gathering, reporting, analyzing, and distributing news/information. These citizens have no journalistic knowledge or experience. Yet, they are capable of utilizing modern technology such as computer, software, and the internet to share their creation, arguments, criticism, and their distribution throughout various available mass media outlets. Although they carry out the process of gathering, reporting, analyzing, and distributing news/information themselves, it is still mediated by mass media. in this perspective, the position of mass media is vital. It has a huge role in communicating information among the pub- lic (Happer \& Philo, 2013). Meanwhile, Lim (2013) states that media has a role as an amplifier, echoing issues existing in the society.

However, currently in Indonesia, citizen journalism has been undergoing a shift. According to informant 3 (initial EN), the shift process happened because a part of the public consider mass media as being a part of the ruling authority because they are owned by conglomerates who also sit as General Chairman in political parties in support of power. Additionally, the shift process happened very quickly on account of social media's presence:

The public tend to choose using social media in reporting information or news they have than via mass media. the public knows, it's like a public secret that mass media are owned by political parties affiliated to the current regime. This is why netizens, who are different from the rulers, to prefer disseminating information through their social media account. Then the opposite happens, in news production, mass media in fact cites several citizen journalism contents disseminated via social media. Particularly when the information or news distributed by citizens on social media go viral.

This phenomenon is another variant that sheds a different understanding on the prior definition of citizen journalism. Lang (2010) states that citizen journalism is a form of journalism produced by nonprofessionals. It may 
come in various forms including texts, images, videos, and audios. It may utilize various tools such as mobile phones, computers, audio recorders, or even mere pen and paper. In this perspective, mass media's position is not too significant due to the presence of internet-based new media, like Twitter. The large number of social media users and democratic climate allowing freedom of expression in Indonesia have intensified social media activities highly, quickly, and instantaneously (real time). Such condition has increasingly driven citizen journalism to no longer be mediated by mass media but social media instead. On Twitter, citizen journalism activities can quickly go viral as they are mobilized by actors known as opinion makers. These opinion makers stand alone on social media, yet they are interconnected between one another. The extremely dynamic context of social media enables anyone to become a character that designs their own desired opinion. This study found that, even on Twitter, opinion leaders or opinion makers may originate from an anonymous account.

Given the various circumstances above, activities on Twitter are exacerbated by the netizens' lack of self control. Suler's (2004) study explains how an individual may express things on social media that they would not in their daily life. This phenomenon is described as the online disinhibition effect. Netizen convey freely what they want to via social media. Some of the information/news distributed may be products of citizen journalism. Some other information/news, however, are public opinions. Some information/news may even carry vague or ambiguous contents, without clarity whether the information/news delivered concerns the public's interest (as public opinion) or political support to a particular presidential/vice-presidential candidate.

Such ambiguity was frequently produced by netizens who were polarized by their political proclivity in the 2014 Presidential Election, which then continued to the 2019 Presidential Election. The developments explained in the above passages show that citizen journalism in the era of new media has paved way for the active participation of netizens. The definition of citizen journalism can no longer be simplified as a process of gathering, reporting, analyzing, and distributing news/information that is obtained independently through mass media because citizen journalism overlaps with public opinion. As mentioned by Franklin (2013), citizen journalism is the process of giving voice to the voiceless, because numerous public opinions are not represented by mainstream media. In the era of new media, citizen journalism may be construed as citizen participation in expressing their opinions. Hence, Goode (2009) explains that citizen journalism assumes the basic features of democracy. This is an expression of the fundamental democratic principle about freedom of speech and expression. What is most crucial is that social media has given citizens the opportunity to talk about their issues (public interest) unrestrictedly thereby making their voices heard by the government.

\section{Conclusion}

Citizen journalism in Indonesia initially emerged via the radio with the advent of the Elshinta News and Talk radio program in Jakarta in 2000 . At the time, social media like Twitter was still nonexistent. The strong verbal communication culture among the citizenry had led to Elshinta's success in involving the public as practitioners of citizen journalism. Elshinta had constantly involved the public in their broadcast to deliver news/information. It is recorded that up till 2007 Elshinta had 100,000 citizen reporters.

Today, however, the presence of social media has gained the public's interest. The substantial scale of internet use by Indonesians has also contributed to the changing or developing of public participation in citizen journalism activities. The public prefers to use social media like Twitter in delivering their news/information. This shift is also due to the fact that mass media, as the mainstream news/information provider, has been considered as a political partisan.

Citizen journalism is entering a new phase in the era of new media. This new phase is similar to a journey about change that occurs within citizen journalism as public participation in the context of new media in Indonesia from street to tweet. The most striking aspect observed in this new phase is the ambiguity between news, information, and opinions conveyed by citizens via social media, such as Twitter. Nevertheless, these activities have provided the opportunity for the public's voice to be heard by the government. Therefore, the public will also gain this benefit when they practice citizen journalism mediated via mass media, which is the mainstream news/information provider.

This study contributes to the concept of citizen journalism and robust learning for the public on their participation and involvement in the era of new media. Additionally, this study provides greater insight on the relationship amongst the citizenry and how they openly engage in discussions of public interest. This research may have implication on the fading of mainstream mass media and the end of the independent and free press era.

\section{Acknowledgments}

We would like to convey our sincere gratitude to our five informants who have shared their experiences and information with us in this study.

\section{Conflict of Interests}

The authors declare no conflict of interests.

\section{References}

Adi, D. S. (2016). Jurnalisme publik \& jurnalisme warga serta perannya dalam meningkatkan partisipasi warga dalam proses demokrasi [Public jour- 
nalism \& citizen journalism and their role in raising public participation in the democracy process]. Nomosleca, 2(1), 342-365.

Asur, S., \& Huberman, B. A. (2010). Predicting the future with social media. In Proceedings of IEEE/WIC/ACM International conference on web intelligence. Washington, DC: IEEE Computer Society. Retrieved from https://arxiv.org/pdf/1003.5699.pdf

Ausserhofer, J., \& Maireder, A. (2013). National politics on Twitter: Structures and topics of a networked public sphere. Information, Communication \& Society, 16(3), 291-314.

Ball-Rokeach, S. J., \& Gutierrez-Hoyt, E. (2001). Communication technology and community. Communication Research, 28(4), 355-357.

Besserman, L. (1998). The challenge of periodization: Old paradigms and new perspectives. Speculum, 73(3), 923.

Bruns, A., \& Burgess, J. E. (2011). The use of Twitter hashtags in the formation of ad hoc publics. Paper presented at 6th European Consortium for Political Research General Conference, University of Iceland, Reykjavik, Iceland.

Castells, M. (2009). The rise of the network society, with a new preface. The information age: Economy, society, and culture volume I. Hoboken: John Wiley \& Sons.

Chadka, K., \& Kavoori, A. (2000). Media imperialism revisited: Some findings from the Asian case. Media, Culture \& Society, 22(4), 415-432.

Creighton, J. L. (2005). The public participation handbook making better decisions through citizen involvement. San Francisco, CA: Jossey-Bass.

Curran, J. (2007). Rethinking media and democracy. In R. Negrine \& J. Stanyer (Eds), The political communication reader (pp. 27-31). London and New York, NY: Routledge.

Danneels, E. (2004). Disruptive technology reconsidered: A critique and research agenda. Journal of Product Innovation Management, 21(4), 246-258.

Donath, J. (2007) Signals in social supernets. Journal of Computer-Mediated Communication, 13(1), 231-251.

Drone Emprit Academic. (2019). Social network analysis. Drone Emprit Academic. Retrieved from https:// academic.droneemprit.id

Flew, T. (2014). New media. South Melbourne: Oxford University Press.

Franklin, B. (Ed.) (2013). The future of newspapers. Hoboken: Taylor and Francis.

Goode, L. (2009). Social news, citizen journalism and democracy. New Media \& Society, 11(8), 1287-1305.

Gordon, E., \& Silva, A. S. (2011). Net locality: Why location matters in a networked world. Chichester and Malden, MA: Wiley-Blackwell.

Gordon, S. (2017). Online communities as agents of change and social movements. Harshey: Information Science Reference.

Green, W. A. (1995). Periodizing world history. History and Theory, 34(2), 99-111.

Happer, C., \& Philo, G. (2013). The role of the media in the construction of public belief and social change. Journal of Social and Political Psychology, 1(1), 321-336.

Hauben, M., \& Hauben, R. (1997). Netizens: on the history and impact of usenet and the internet. Los Alamitos, CA: IEEE Computer Society Press.

Hecht, B., \& Stephens, M. (2014). A tale of cities: Urban biases in volunteered geographic information. In Proceedings of the Eighth International AAAI Conference on Weblogs and Social Media (pp. 197-205). Retrieved from https://www.aaai.org/ocs/index.php/ ICWSM/ICWSM14/paper/view/8114

Indonesian Internet Service Providers Association. (2017). Infografis penetrasi dan prilaku pengguna internet di Indonesia [Infographic on the penetration and behaviour of internet users in Indonesia]. Retrieved from https://www.apjii.or.id/content/read/ 39/264/Survei-Internet-APJII-2017

Keeter, S. K. (2003). Three core measures of communitybased civic engagement: Evidence from the youth civic engagement indicators project. Paper presented at the Child Trends Conference on Indicators of Positive Development, Washington, DC, USA.

Kerr, A. (2001). Digital media, nation-states and local cultures: The case of multi- media 'content' production. Media, Culture \& Society, 23(1), 109-113.

Keyes, R. (2013). The post truth era: Dishonesty and deception in contemporary life. New York, NY: St. Martin's Press.

Khang, H., Ki, E., \& Ye, L. (2012). Social media research in advertising, communication, marketing and public relations, 1997-2010. Journalism and Mass Communication Quarterly, 89(2), 279-298.

Kitchin, R., \& Dodge, M. (2011). Code/space: Software and everyday life. Cambridge, MA: MIT Press.

Kolodzy, J. (2007). Convergence journalism: Writing and reporting across the news media. Lanham: Rowman \& Littlefield.

Kurniawan, M. N. (2007). Jurnalisme warga di Indonesia: Prospek dan tantangannya [Citizen journalism in Indonesia: Prospects and Challenges]. Makara, Sosial Humaniora, 11(2), 71-78.

Kurniawan, M. N., \& Loo, E. (2007). Radio Elshinta, no music, just news and stories as the people see it. Media Asia, 3(2), 96-104.

Lang, S. (2010). Water polo vs. no water: Citizen journalism has to support marginalized communities. Paper presented at the International Media Conference, Berlin, Germany.

Lefebvre, H. (2016). The production of space. Malden, MA: Blackwell.

Lessig, L. (2001). The Future of ideas. New York, NY: Random House.

Levinson, P. (2014). New new media. Boston, MA: Pearson.

Lim, M. (2011). @Crossroads: Democratization and corporatization of media in Indonesia. Tempe, AZ: Ari- 
zona State University and Ford Foundation.

Lim, M. (2012). The league of thirteen media concentration in Indonesia. Tempe, AZ: Arizona State University and Ford Foundation.

Lim, M. (2013). The internet and everyday life in Indonesia: A new moral panic? Bijdragen tot de Taal-, Landen Volkenkunde, 169(1), 133-147.

Lim, M. (2014). Many clicks but little sticks: Social media activism in Indonesia. Journal of Contemporary Asia, 43(4), 636-657.

Lim, M. (2017). Freedom to hate: Social media, algorithmic enclaves, and the rise of tribal nationalism in Indonesia. Critical Asian Studies, 49(3), 411-427.

Low, P. C. (2003). The media in a society in transition, a case study of Indonesia (MA Thesis). The Fletcher School, Tufts University, Medford, USA.

Lukman, E. (2013). Indonesia is social: $2.4 \%$ of world's Twitter posts come from Jakarta (INFOGRAPHIC). Retrieved from https://www.techinasia.com/ indonesia-social-jakarta-infographic

Macek, J. (2004). Defining cyberculture. Retrieved from http://macek.czechian.net/defining_cyberculture. htm

Malik, M. M., Lamba, H., Nakos, C., \& Pfeffer, J. (2015). Population bias in geo-tagged tweets. Paper presented at the 2015 ICWSM Workshop on Standards and Practices in Large-Scale Social Media Research (pp. 18-27). Retrieved from http://www. aaai.org/ocs/index.php/ICWSM/ICWSM15/paper/ view/10662

Mietzner, M. (2015). Reinventing Asian populism: Jokowi's rise, democracy, and political contestation in Indonesia. Singapura: ISEAS.

Mislove, A., Lehmann, S., Ahn, Y.-Y., Onnela, J.-P., \& Rosenquist, J. N. (2011). Understanding the demographics of Twitter users. In Proceedings of the Fifth International AAAI Conference on Weblogs and Social Media (pp. 554-557). Retrieved from https://www.aaai. org/ocs/index.php/ICWSM/ICWSM11

Nainggolan, B. (2017). Market typology, concentration, and competition of national media conglomerate in Indonesia. Jurnal Komunikasi Ikatan Sarjana Komunikasi Indonesia, 2(1), 27-32.

Nugroho, Y., Putri, D. A., \& Laksmi, S. (2012). Memetakan lansekap industri media kontemporer di Indonesia [Mapping out the landscape of contemporary media industry in Indonesia]. Jakarta: Edisi Bahasa Indonesia.

Nugroho, Y., Siregar, M. A., \& Laksmi, S. (2012). Laporan. Bermedia, memberdayakan masyarakat: Memahami kebijakan dan tatakelola media di Indonesia melalui kacamata hak warga negara [Report. Conducting media, empowering community: Understanding policies and organization of media in Indonesia through the perspective of citizen's rights]. Jakarta: CIPG and HIVOS.

Nugroho, Y., \& Syarief, S. S. (2012). Beyond clickactivism? New media and political processes in contemporary Indonesia. Jakarta: Friedrich Ebert Stiftung.

Pavlik, J. (2001). Journalism and mew media. New York, NY: Columbia University Press.

Santoso, A. (2019). \#JusticeForAudrey, viral siswi SMP dikeroyok belasan siswi SMA di Pontianak [\#JusticeForAudrey, junior high school girl beaten up by high school girls in Pontianak gone viral]. Detik.com. Retrieved from https://news.detik.com/ berita/d-4502768/justiceforaudrey-viral-siswi-smpdikeroyok-belasan-siswi-sma-di-pontianak

Schultz, T. (2000). Mass media and the concept of interactivity: An exploratory study of online forums and reader email. Media Culture \& Society, 22(2), 205-221.

Strelitz, L., \& Steenveld, L. (1998). The fifth estate: Media theory, watchdog of journalism. Ecquid Novi: African Journalism Studies, 19(1), 100-110.

Sukartik, D. (2016). Peran jurnalisme warga dalam mengakomodir aspirasi masyarakat [The role of citizen journalism in accommodating public aspirations]. Risalah, 27(1), 10-16.

Suler, J. (2004). The online disinhibition effect. Cyberpsychology and Behavior, 7(3), 321-325.

Syahputra, I. (2013). Rezim media: Pergulatan demokrasi, jurnalisme dan infotainment dalam industri televisi [Media regime: The struggle of democracy, journalism, and infotainment in the television industry]. Jakarta: Gramedia.

Syahputra, I. (2017). Demokrasi virtual dan perang siber di media sosial: Perspektif netizen Indonesia [Virtual democracy and cyber war on social media: The perspective of Indonesian netizens]. Jurnal ASPIKOM, $3(3), 457-475$.

Tesich, S. (1992, January 6). A government of lies. The Nation. Retrieved from https://drive.google.com/ file/d/OBynDrdYrCLNtdmtOSFZFeGMtZUFsT1NmTGV TQmc1dEpmUC1z/view

Thomas, K., Grier, C., \& Paxson, V. (2011). Suspended accounts in retrospect: An analysis of twitter spam. In Proceedings of the 2011 ACM SIGCOMM conference on internet measurement. New York, NY: ACM. Retrieved from http://conferences.sigcomm.org/imc/ 2011/docs/p243.pdf

Thomas, K., McCoy, D., Grier, C., Kolcz, A., \& Paxson, V. (2013). Trafficking fraudulent accounts: The role of the underground market in twitter spam and abuse. In Proceedings of the 22nd usenix security symposium. Berkeley, CA: USENIX Association. Retrieved from https://www.usenix.org/system/files/ conference/usenixsecurity13/sec13-paper_thomas. pdf

We Are Social. (2018). Global digital report 2018. Retrieved from https://wearesocial.com/blog/2018/ 01/global-digital-report-2018

Weeks, B. E., \& Holbert, R. L. (2013). Predicting dissemination of news content in social media: A focus on reception, friending and partisanship. Journalism and 
Mass Communication Quarterly, 90(2), 212-232.

White, A. (2017). Ethic in the news: EJN report on challenges for journalism in the post-truth era. London: Ethical Journalism Network.
Widodo, Y. (2010). Menyoal etika jurnalisme kontemporer: Belajar dari OhmyNews [Questioning contemporary journalism ethics: Lessons from OhmyNews]. Jurnal ASPIKOM, 1(1), 41-59.

\section{About the Authors}

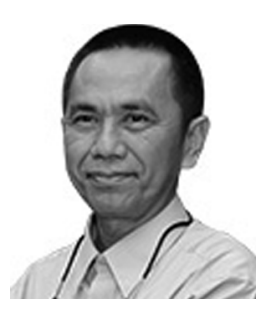

Rajab Ritonga is currently an Associate Professor at the Faculty of Communication, University of Prof. Dr. Moestopo (Beragama) in Jakarta. He received his BA degree in Communication Science at Gadjah Mada University in 1986, MS and PhD degrees in Mass Communication at University of Indonesia in 2001 and 2007 respectively. From 1987 to 2012, he worked as a journalist at Antara, Indonesian National News Agency. His research interests are in the areas of journalism, media, social media, and mass communication.

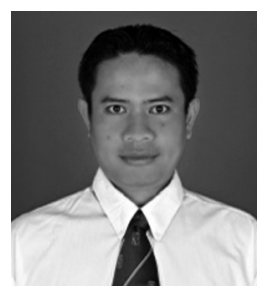

Iswandi Syahputra is a Lecturer at the Study Program of Communication Sciences, Faculty of Social Sciences and Humanities, Sunan Kalijaga State Islamic University, Yogyakarta. He has a PhD degree in Cultural Studies and Media from University of Gadjah Mada, Yogyakarta. From 2000 to 2004, he worked as a Reporter at Radio Elshinta News and Talk, Jakarta. His main points of interest pertain to research on religion and new media, social media and social movement, politics and social media. 